\title{
O DESEVANGELHO DE TEODORICO RAPOSO: O RISO E A DESCONSTRUÇÃO DO TEXTO BÍBLICO EM A RELÍQUIA, DE EÇA DE QUEIRÓS
}

\author{
The Spurious Gospel of Teodorico Raposo: the laughter and descontruction of \\ Bible in "The Relic', by Eça de Queirós
}

\author{
Charles Vitor Berndt* \\ Salma Ferraz ${ }^{* *}$ \\ Universidade Federal de Santa Catarina
}

\begin{abstract}
Resumo: O objetivo deste trabalho é apresentar uma análise acerca de alguns aspectos da novela $A$ relíquia, de Eça de Queirós, publicada pela primeira vez em 1887. Tal como o faz em $O$ Mandarim (1880), em A relíquia o escritor português afasta-se parcialmente do naturalismorealismo, movimento literário ao qual se enfeudara ao longo de sua vida, e volta a explorar o gênero fantástico, apresentando-nos desta vez uma narrativa que estabelece grande intertextualidade com o texto bíblico. Contudo, como é típico de Eça, autor de romances como O crime do padre Amaro (1875), por mais que haja uma aposta na fantasia e em elementos fantásticos, é possível perceber sempre uma determinada crítica social, possibilitando que o leitor se depare com um texto extremamente sarcástico, irônico, que procura não apenas retratar o conservadorismo da sociedade portuguesa do século XIX, mas sobretudo desvelar e desconstruir as suas hipocrisias e os seus falsos moralismos, advindos das práticas e crenças religiosas do catolicismo português. Dessa maneira, buscar-se-á discutir o texto queirosiano a partir do olhar da Teopoética e, mais especificamente, de um novo campo de estudo que tem surgido no Brasil nas discussões que procuram comparar a Bíblia e a Literatura, denominado de Teologia do Riso. Ver-se-á, então, o quanto o riso, o humor, o escárnio, ao lado da utilização constante de alegorias e metáforas, são a principal arma queirosiana para dessacralizar o texto bíblico e lançar uma crítica à religião enquanto instituição, ao mesmo tempo em que, de forma inusitada, através das peripécias e dos sonhos do narrador personagem, Teodorico Raposo, conduz o leitor numa viagem pelo país do Evangelho, pela cidade sagrada de Jerusalém e pelas
\end{abstract}

(c)

(i)

Esta obra está licenciada sob uma Creative Commons - Atribuição 4.0

\footnotetext{
* Mestre em Literatura. Atualmente é doutorando do Programa de Pós-graduação em Literatura da Universidade Federal de Santa Catarina. E-mail: charlesatlantis@gmail.com.

iD http://orcid.org/0000-0002-5382-7189

** É professora associada de Literatura Portuguesa no Departamento de Língua e Literaturas Vernáculas da UFSC; Pós-doutora em Literatura pela UFMG (2008); coordenadora do Núcleo de Estudos Comparados entre Teologia e Literatura (NUTEL). E-mail: salmaferraz@gmail.com.
}

iD https://orcid.org/0000-0001-9344-5612 
ruas e lugares por onde o Messias cristão tantas vezes teria passado, pregando sua doutrina e curando cegos e aleijados.

Palavras-chave: A relíquia. Eça de Queirós. Bíblia. Riso. Teologia do Riso.

Abstract: This work intends to present an analysis of some aspects of the novel "The Relic", by Eça de Queirós, first published in 1887. In this book, the Portuguese writer does the same as in "The Mandarin" (1880), moving partially away from Realism and Naturalism, literary movements he was dedicated to throughout his life, to explore once again the fantasy genre. This time Eça de Queirós presents a narrative that shows great intertextuality with biblical texts. However, typical as it is of Eça, who wrote novels such as "The Sin of Father Amaro" (1875), the presence of social critique is also there, despite the use of fantastic elements in such work, what makes the reader come across an extremely sarcastic and ironic text that not only depicts the conservatism of Portuguese society in the 19th Century but also - and most of all - reveals its hypocrisy and fake morality, which were originated from Portuguese Catholicism practices. Thus, this work aims at discussing Eça de Queiróz's text from the perspective of Theopoetics and more specifically the Theology of Laughter, a new field of study emerged in Brazil that tries to compare the Bible and Literature. It will be seen, then, how laughter, humor and mockery, alongside the use of allegories and metaphors, are Eça's main tools to desecrate the biblical text and criticize religion as an institution. At the same time, in an unusual way, the author uses the adventures and dreams of Teodorico Raposo, the first-person narrator in "The Relic", to lead the reader on a trip to the Land of the Gospel, the sacred city of Jerusalem and the streets and places where the Christian Messiah so many times passed by, preaching his doctrine and healing blind men and cripples.

Keywords: The Relic. Eça de Queirós. Bible. Laughter. Theology of Laughter.

Recebido em: 19/04/2018

Acesso em: 11/07/2018

\section{A Bíblia, a Literatura e a Teologia do Riso}

Não há dúvida do quanto a Bíblia é um texto importante na cultura ocidental - parece claro, para todos nós, sujeitos imersos em países de cultura majoritariamente cristã, o quanto os livros que compõem o que se convencionou chamar de Bíblia Sagrada influenciaram e ainda influenciam nossa cultura, nossos costumes, nosso modo de pensar e, sobretudo, nossas crenças religiosas. Contudo, enquanto um texto extremamente rico, complexo e polissêmico, a narrativa bíblica ultrapassa o universo religioso e teológico, suscitando, a partir do século $\mathrm{XX}$ principalmente, uma série de análises e discussões dentro de áreas como a crítica literária, por exemplo. A esse campo de estudo, que procura encarar a Bíblia como um texto literário, antes de qualquer coisa, "levando em conta tramas, personagens, estética, densidade, narrativa, etc." (MAGALHÃES, 2008, p. 1), no Brasil tem-se denominado de Teopoética.

Assim, sobre o crescimento de estudos e análises dentro do campo da Teopoética no Brasil e em Portugal, é importante considerar que

As relações entre a teologia e a literatura são muito complexas e diversificadas e só recentemente têm sido objeto de uma reflexão sistemática. No Ocidente, desde a consolidação da escolástica nos sécs. XII e XIII - com teólogos do porte de Santo Alberto Magno, São Tomás de Aquino ou São Boaventura - 
até o séc. $\mathrm{XX}$, a teologia acadêmica quase sempre ignorou completamente a existência e a importância da literatura, não obstante a evidente relevância das questões teológicas nas obras de autores como Dante, Gil Vicente, Camões, Calderón, Milton, Hopkins, Antero de Quental ou Dostoiévski, por um lado e, por outro, o freqüente recurso à linguagem poética por parte de alguns dos mais insignes místicos cristãos, como são João da Cruz ou Santa Teresa de Ávila, ou ainda a manifesta qualidade literária dos textos de oradores sacros como Vieira ou Bossuet. (BARCELLOS, 2017)

Zapatiero e Leonel (2011), recorrendo sobretudo às discussões de Robert Alter, ressaltam que, em grande medida, sempre foi mais comum se analisar a Bíblia sob o ponto de vista historicista, desenvolvendo análises e estudos que procuravam investigar a veracidade histórica de suas personagens, lugares e acontecimentos narrados. Já no que diz respeito às análises dentro do campo da literatura, os autores relembram que a maior dificuldade residia na concepção, por parte dos críticos literários, de que o texto bíblico se trata apenas de um livro sagrado, religioso, compreendido como um texto de inspiração divina, a serviço da doutrinação religiosa. Desse modo, essa visão promoveu o surgimento de uma "abordagem unidirecional" (ZABATIERO; LEONEL, 2011, p. 20), em que a Bíblia passou a ser lida, percebida e discutida apenas a partir de seu aspecto dogmático, ignorando-se, inclusive, o quanto ela é um texto vasto, pluralizado, escrito ao longo de séculos, em que estão presentes diversos gêneros literários e estilos narrativos. Nesse sentido, o que faltou, durante muito tempo, foi a compreensão, por parte de teólogos e críticos literários, do que é de fato um texto, seja ele bíblico ou não (ZABATIERO; LEONEL, 2011, p. 21).

Assim, Zapatiero e Leonel (2011) defendem que se faz necessário que encaremos a literatura enquanto "mimesis, ou seja, enquanto imitação e representação da realidade, e como poiesis, isto é, como criação e transformação da realidade" (ZABATIERO; LEONEL, 2011, p. 21). Em outras palavras, quando falam de mímeses, o que os autores nos dizem é que um texto literário possui sempre uma relação intermediária com a realidade, buscando representá-la, imitá-la, na medida em que foi escrito por alguém, expressando sempre um determinado ponto de vista. Quanto à poiesis, ao poder de criar e de transformar a realidade, os autores recordam que todo texto é uma "ponte entre o que se deu em algum momento pretérito e o presente que se constrói no ato da leitura", daí a importância do leitor, da interação que este estabelece com o texto e nos novos sentidos, nas novas realidades, que é capaz de criar.

A Bíblia está repleta de histórias e, para além de seu caráter doutrinário e das análises historicistas que possibilita, é inegável o seu caráter enquanto texto, enquanto texto literário. Negar isso significa reduzir violentamente as possibilidades interpretativas que nos fornece a sua leitura, bem como elementos centrais da sua própria composição e tessitura textual. Dessa maneira, Magalhães (2008) acentua que

[...] o literário da Bíblia não pode ser compreendido em profundidade sem que se leve em consideração que a narrativa [bíblica] é constituída por concepções religiosas e teológicas [...] Não é possível nem desejável estabelecer uma diferença abissal entre o que é teológico e o que é literário na Bíblia, pois os âmbitos se confundem, interagem de forma densa e 
complexa. Seria a mesma coisa se quiséssemos estabelecer a diferença nítida entre mito religioso e mito literário em Homero. (MAGALHÃES, 2008 , p. 3, grifo nosso)

Diferentemente de grande parte dos textos literários da literatura ocidental, Magalhães (2008) nos diz que “os textos bíblicos são sucintos” (MAGALHÃES, 2008, p. 3) e a sua riqueza reside "mais na complexidade e imensidade de tramas e personagens que na narração prolixa e detalhista" (MAGALHÃES, 2008, p. 3), como estamos acostumados a ver em Homero, por exemplo. Auerbach evidencia essa questão muito bem em seu livro Mimesis, no primeiro capítulo intitulado A cicatriz de Ulisses, quando mostra as diferenças entre o estilo de narração homérica e o estilo de narração presente no Velho Testamento:

Os dois estilos representam, na sua oposição, tipos básicos: por um lado, descrição modeladora, iluminação uniforme, ligação sem interstícios, locução livre, predominância do primeiro plano, univocidade, limitação quanto ao desenvolvimento histórico e quanto ao humanamente problemático; por outro lado, realçamento de certas partes e escurecimento de outras, falta de conexão, efeito sugestivo do tácito, multiplicidade de planos, multivocidade e necessidade de interpretação, pretensão à universalidade histórica, desenvolvimento da apresentação do devir histórico e aprofundamento do problemático. (AUERBACH, 2011, p. 20)

Dessa forma, os estudos de Teopoética, no Brasil e no mundo, nos últimos anos, têm contribuído de forma decisiva para que cada vez mais se possa perceber e discutir a relevância da Bíblia para a literatura - a sua constante influência sobre uma vasta quantidade de texto literários e a sua importante presença em estudos acadêmicos, dentro dos Estudos Literários. Assim, entre tantas questões já colocadas e outras ainda por serem aprofundadas e propostas, recentemente tem surgido no contexto brasileiro uma área bastante interessante dentro dos estudos de Teopoética denominada de Teologia do Riso. Damos destaque à discussão empreendida por Ferraz (2014), intitulada "É certo que riste: Humor no Cristianismo", em que a autora aponta uma série de elementos cômicos e humorísticos em diversas narrativas bíblicas, sobretudo no Velho Testamento:

A serpente enganou Eva, que enganou a Adão que acusou Eva que acusou a Serpente. Sara riu da promessa de HHVH lhe dar um filho na sua velhice. Jacó enganou Isaac, roubou a primogenitura de seu irmão Esaú e se fez passar por ele perante o seu pai. Mais tarde Jacó é enganado por Labão que lhe dá como esposa Lia no lugar da amada Raquel. As matriarcas disputam a atenção sexual do Patriarca colhendo Mandrágoras, uma espécie de Viagra da época. O Patriarca também é enganado por seus filhos, liderados por Judá que vendem José como escravo para mercadores do Egito. José do Egito engana seus irmãos ao não se revelar para eles. Judá engana sua nora Tamar ao não dar seu terceiro filho como esposo para esta, desrespeitando a lei do Levirato. Tamar por sua vez engana a seu sogro e agora viúvo Judá, disfarçando-se por uma meretriz e tendo um filho dele, o que lhe vai garantir sua descendência (FERRAZ, 2014, p. 122-123).

Dentro dessa nova área de discussão nos estudos de Teopoética, ressalta-se, ainda, o 
livro de Ferraz et al (2017), intitulado Teologia do Riso: Humor e Mau humor na Bíblia e no Cristianismo, em que são reunidos diversos textos sobre a presença do riso, do humor, do cômico, da ironia na Bíblia e na literatura por ela influenciada, incluindo-se textos veiculados recentemente na internet. Nesse sentido, é importante salientar que

O humor e o riso corroboram com a construção de uma visão de mundo, permitindo que através do riso se construa novos pontos de vista, exercício da imaginação e novas concepções de aspectos divinos e sua relação com o ser humano, sua fé e suas dúvidas. No que se refere ao humor e ao riso ligados ao textos bíblico, não se trata de uma forma de fuga e afastamento do que está escrito na Bíblia, mas sim outro olhar sobre a obra literária - não somente sagrada, e a autopermissão de se questionar e aprofundar alguns conceitos a partir da leitura realizar através do humor. (SILVEIRA, 2017, p. 45, grifo nosso)

O humor surge, então, como ferramenta de análise, de discussão, de problematização, de crítica, que nos auxilia a repensar diversos aspectos da Bíblia enquanto texto literário, bem como nos ajuda a lançar novos olhares para o Cristianismo e para nossa própria cultura. Afinal de contas, como lembra Ferraz (2014), por que Jesus é sempre retratado - nas pinturas, esculturas e imagens que conhecemos - com uma expressão de dor? Por que não há espaço para o riso dentro do Cristianismo, dentro da Teologia? Para Duarte (2006), o ser humano ri porque sabe que irá um dia morrer. O riso é, desse modo, uma experiência transgressora:

O riso revela-se útil, assim, para a manutenção da espécie: experiência do não saber, livra do desespero do pensamento aprisionado nos limites do sério. Nesse sentido, saber rir é momentaneamente torna-se "Deus", experimentar o impensável, sair da finitude da existência. (DUARTE, 2006, p. 53)

Enquanto importante ferramenta de crítica e de reflexão, o riso sempre esteve presente na literatura, no teatro, na arte de modo geral. Podemos recordar, por exemplo, das famosas cantigas de escárnio e de maldizer da lírica portuguesa trovadoresca. $\mathrm{O}$ elemento humorístico nesses textos estava, muitas vezes, a serviço de uma crítica social e moral que se desejava fazer, é por isso que vemos figuras importantes, como reis, nobres e clérigos, sendo ridicularizadas, escarnecidas, tendo sua intimidade e vulnerabilidades reveladas. $\mathrm{O}$ riso, assim, cumpre sua função, como nos sugere Duarte (2006), de tentar vencer a morte, de tentar vencer nossa situação de seres mortais e frágeis, ao mesmo tempo em que assume sua "[...] função social e educadora: ridendo, castigat mores" (DUARTE, 2006, p. 57).

$\mathrm{Na}$ literatura portuguesa, a presença do riso, do humor, da ironia como ferramenta de crítica social sempre foi uma constante, destacando-se a sua importância desde as cantigas trovadorescas, como já citamos, até o teatro de Gil Vicente e, mais tarde, no século XIX, nas narrativas de Eça de Queirós - autor que nos interessa particularmente nesta discussão. Para Duarte (2006),

Eça critica a degradação do clero e da família e a política de interesses em obras como $O$ crime do padre Amaro (onde as caricaturas burlescas do padre Brito, das beatas enfeitadas e da figura saltitante do Libaninho provocam o 
riso), O primo Basílio (com as figuras risíveis do Conselheiro Acácio e de D. Felicidade), A relíquia (com a secura desejante da Titi e a sensualidade obscena dos padres e do próprio Teodorico), Alves \& Cia (com o desamparo risível do marido traído) e $\mathrm{O}$ Conde de Abranhos (com o depoimento ingênuo do secretário adulador). Nesse sentido, a obra de Eça de Queirós será um bom exemplo do riso "engajado", com base na ironia e privilégio da significação, presença marcante no enunciado textual e função ideologicamente pedagógica. (DUARTE, 2006, p. 61)

Até mesmo em textos vistos comumente pela crítica como mais fantásticos que realistas, como é o caso do conto $O$ mandarim e da novela $A$ relíquia, nota-se o quanto o humor surge como um importante elemento a serviço de uma dura crítica social, de uma vontade de romper com modelos, regras, convicções e ideias fixas (DUARTE, 2006, p. 61). Justifica-se e compreende-se, portanto, a frase "Sobre a nudez forte da realidade, o manto diáfano da fantasia", subtítulo de $A$ relíquia, que evidencia o quanto para o escritor português "a função da arte seria a de criar uma "ilusão de real", produzida a partir de uma observação indireta desse real" (DUARTE, 2006, p. 61).

Dessa maneira, passaremos, em seguida, à análise e discussão de alguns aspectos que dizem respeito mais especificamente à novela $A$ relíquia, publicada por Eça de Queirós em 1887, de modo a perceber como o riso, o humor, o cômico são ferramentas fundamentais nesta narrativa para a realização de uma crítica social e religiosa, bem como a sua intensa relação intertextual com os textos bíblicos, com intuito de dessacralizá-los e desconstruí-los, ressaltando, a nosso ver, a sua relevância nas discussões que envolvem a Teopoética e a Teologia do riso.

\section{Bíblia, riso e desconstrução em Eça de Queirós}

Na obra Eça de Queirós, A relíquia destaca-se por conta de sua "avultante intertextualidade com o texto bíblico" (NERY, 2011, p. 01), com a intenção de desconstruí-lo e dessacralizá-lo, principalmente. A crítica e referência à Bíblia à religião, todavia, é algo que percorre grande parte dos textos queirosianos, destacando-se, obviamente, romances como $O$ crime do padre Amaro, publicado em 1871. Desse modo, não se pode ignorar que Eça de Queirós estava inserido nas discussões levantadas pela famosa Geração de 70, na segunda metade do século XIX, e sua obra reflete uma grande quantidade de princípios, pensamentos e críticas colocados por escritores como Antero de Quental, por exemplo.

Em um famoso discurso intitulado Causas da Decadencia dos Povos Peninsulares nos últimos três séculos, proferido em 1871, Antero de Quental elabora justamente um panorama do que, na sua visão, constituem as principais causas da decadência ibérica a partir século XVII até a sua época, o século XIX. Assim, olhando para a Europa industrializada e científica de então, berço do Iluminismo, das grandes ideias, do avanço tecnológico, o escritor enxerga "o Catolicismo difundido após o Concílio de Trento (1545-1563), a monarquia absolutista e as conquistas ultramarinas como os três principais motivos causadores da decadência moral, econômica e social das nações ibéricas" (NERY, 2013, p. 34). Em suma, o que mais 
incomodava Antero era perceber o que na sua visão constituía um atraso econômico e científíco de Portugal e Espanha, sempre tendo como ponto de comparação países como a França e a Inglaterra.

Eça de Queirós, de alguma maneira, estava envolvido nessas questões e parecia concordar com o pensamento que orienta o discurso de Antero de Quental, sobretudo com a crítica religiosa direcionada à Igreja Católica Oitocentista. Mas segundo Nery (2013), o que se vê a obra queirosiana não se trata apenas de um sentimento antirreligioso e de uma crítica direcionada ao clero católico português. Trata-se, em verdade, de uma "valorização de algumas práticas religiosas muito próximas daquelas descritas positivamente por Antero em suas referências às "Igrejas Nacionaes", além de engendrar reflexões concernentes ao caráter transcendente da religião" (NERY, 2013, p. 36). Em outras palavras, o que se percebe, na visão do autor, em narrativas como A relíquia e está em consonância com o pensamento de Antero de Quental não é a crítica irrestrita à fé religiosa e a qualquer experiência de ordem supersticiosa e transcendental, mas à religião enquanto Instituição.

Nesse sentido, ainda que $A$ relíquia seja comumente referido como um texto de caráter fantástico, em que há um grande uso de alegorias, tal como acontece no conto $O$ mandarim (1880), pode-se perceber a sua relação com o espírito objetivo e racional do escritor realista o qual Eça de Queirós nunca deixou de ser. Portanto, o que o autor faz em sua novela é “[...] usar e abusar do humor, da ironia e da fantasia, não como atitudes opostas a um espírito objetivo, mas como outra forma possível de apreensão da realidade. (NERY, 2013, p. 37).

Quanto ao enredo da novela, temos um narrador personagem, Teodorico Raposo, que se coloca a narrar, através de um discurso repleto de ironias, uma viagem que realizara na sua juventude à Terra Santa, à cidade de Jerusalém:

Em 1875, nas vésperas de Santo António, uma desilusão de incomparável amargura abalou o meu ser; por esse tempo minha tia, D. Patrocínio das Neves, mandou-me do Campo de Santana onde morávamos, em romagem a Jerusalém; dentro dessas santas muralhas, num dia abrasado do mês de Nizam, sendo Poncio Pilatos procurador da Judeia, Élio Lama, Legado Imperial da Síria, e J. Cairás, Sumo Pontífice, testemunhei, miraculosamente, escandalosos sucessos; depois voltei, e uma grande mudança se fez nos meus bens e na minha moral. (QUEIRÓS, 2014, p. 13)

Assim, ficamos logo saber, já no prefácio do texto, que essa viagem fora custeada pela mulher que o havia criado depois da morte dos pais, sua rica e beata tia, Dona Patrocínio das Neves. Em verdade, já nesta primeira parte da narrativa, Teodorico nos antecipa uma série de acontecimentos que ainda nos irá narrar, além de anunciar, também, o próprio tom irônico e sarcástico que marcará todo o texto. Dessa maneira, o que mais chama atenção desde o princípio da novela de Eça de Queirós é o modo como Teodorico descreve não só a Terra Santa, mas a própria figura de Jesus e muitos dos principais elementos da religião cristã:

De resto esse país do Evangelho, que tanto fascina a humanidade sensível, e bem menos interessante que o meu seco e paterno Alentejo; nem me parece que as terras, favorecidas por uma presença messiânica, ganhem jamais em 
graça ou esplendor. Nunca me foi dado percorrer os lugares santos da Índia em que o Buda viveu, arvoredos de Migadaia, outeiros de Veluvana, ou esse doce vale de Rajágria, por onde se alongavam os olhos adoráveis do Mestre perfeito, quando um fogo rebentou nos juncais, e Ele ensinou, em singela parábola, como a ignorância é uma fogueira que devora o homem, alimentada pelas enganosas sensações de vida, que os sentidos recebem das enganosas aparências do mundo. Também não visitei a caverna de Hira, nem os devotos arcais entre Meca e Medina, que tantas vezes trilhou Maomé, o profeta excelente, lento e pensativo sobre o seu dromedário. Mas, desde as figueiras de Betânia até as águas coladas de Galileia, conheço bem os sítios onde habitou esse outro intermediário divino, cheio de enternecimento e de sonhos, a quem chamamos Jesus Nosso Senhor; e só neles achei bruteza, secura, sordidez, soledade e entulho. (QUEIRÓS, 2014, p. 14-15, grifo nosso)

O modo como são descritos os profetas de outras religiões - Buda é o "Mestre perfeito", Maomé é o "profeta excelente" - tem por objetivo desvalorizar e satirizar a figura de Jesus Cristo e o próprio Cristianismo, descrito, em outro momento da narrativa, como a religião responsável por espalhar sobre a Terra um "um inenarrável tédio" (QUEIRÓS, 2014, p. 86). A cidade de Jerusalém, por sua vez, é descrita quase sempre como um lugar pobre, fétido, repleto de andarilhos e mendigos, "uma vila turca com vielas andrajosas, acaçapada entre muralhas cor de lodo e fedendo ao sul sob o badalar de sinos tristes" (QUEIRÓS, 2014, p. 14). Já o Jordão, rio no qual João Batista batiza Jesus Cristo no Novo Testamento, será descrito como "um fio de água barrento e peco que se arrasta entre os areais" (QUEIRÓS, 2014, p. 14), muito diferente do rio Lima, que atravessa a região norte de Portugal, descrito como um rio mais belo e verde do que aquele, ainda que as suas águas nunca tenham passado "[...] entre os joelhos de um Messias" (QUEIRÓS, 2014, p. 15). Nery (2011) recorda, assim, que há, ao longo da novela, constantes comparações com Portugal, "[...] sempre ressaltando as qualidades do país em detrimento do oriente, em um processo de desconstrução e dessacralização do lugar sagrado" (NERY, 2011, p. 3). Portanto,

[...] o narrador não esconde desde os primeiros momentos de seu discurso, os comentários nada positivos sobre a terra santa, pois, se ele reconhece sua ignorância geográfica e histórica acerca de outros famosos espaços sagrados, isso não acontece com a terra de Jesus, espaço no qual boa parte da história que ele contará se passa e onde encontrou "bruteza, secura, sordidez, soledade e entulho". (NERY, 2011, p. 3)

A verdade é que a viagem à Terra Santa surge como uma oportunidade de fuga e de libertação para Teodorico, que, para agradar a tia beata e carola, precisava viver uma vida dupla em Portugal, fingindo ser casto e beato. Descrita como a "hedionda senhora" (QUEIRÓS, 2014, p. 231), Dona Patrocínio das Neves nos é apresentada por seu sobrinho como uma mulher extremamente mesquinha, que condenava todas as formas de amor: "E não lhe bastava reprovar o amor como coisa profana: a Sr. ${ }^{a}$ D. Patrocínio das Neves fazia uma carantonha, e varria-o como coisa suja. Um moço grave, amando seriamente, era para si "uma porcaria!". Quando sabia de uma senhora que tivera um filho, cuspia para o lado e rosnava - "que nojo". E quase 
achava a Natureza obscena por ter criado dois sexos" (QUEIRÓS, 2014, p. 42).

Assim, Nery (2013) ressalta que a crítica anticlerical e antirreligiosa presente em $A$ relíquia, com objetivo de desvelar a hipocrisia do clero e da sociedade portuguesa oitocentista, além de se manifestar no comportamento hipócrita, mentiroso e contraditório de Teodorico e no modo como ele próprio descreve o Cristianismo e a Terra Santa, manifesta-se, também, através de outras personagens. É o caso, por exemplo, da tia Patrocínio, que além de se demonstrar uma pessoa fria, que condena qualquer forma de amor e de afeto, apresenta um comportamento cruel e egoísta, indo contra, inclusive, aos valores mais caros ao Cristianismo, como a caridade e a fraternidade. Isso se torna evidente quando ela se nega a ajudar a família de um amigo pobre de Teodorico, que passa por dificuldades, respondendo: "Não tem o perdão de Deus, nem tem o meu! Que padeça, que padeça, que também Nosso Senhor Jesus Cristo padeceu!" (QUEIRÓS, 2014, p. 32).

Outrossim, Teodorico parte para a Terra Santa com intuito de trazer à Titi, como ele mesmo a chama, uma relíquia santa, capaz de devolver-lhe a saúde, já que ela diz estar doente. Entretanto, assim que deixa Lisboa, o que ele faz é assumir sua verdadeira personalidade, preocupando-se em desfrutar do prazer que as mulheres poderiam the oferecer. No meio da viagem, quando chega ao Egito, então, envolve-se com uma inglesa, dona de uma loja de luvas e flores-de-cera, chamada Mary, a quem apelida de Maricoquinhas:

Ela amava a minha barba negra e potente; e, só para não me afastar do calor das suas saias, eu renunciei a ver o Cairo, o Nilo, e a eterna Esfinge, deitada à porta do deserto, sorrindo da humanidade vã... Vestido de branco como um lírio, eu gozava manhãs inefáveis, encostado ao balcão da Mary; amaciando respeitosamente a espinha do gato. Ela era silenciosa; mas o seu simples sorrir com os braços cruzados, ou o seu modo gentil de dobrar o Times, saturava o meu coração de luminosa alegria. Nem precisava chamar-me "seu portuguesinho valente, seu bibichinho". Bastava que o seu peito arfasse; só para ver aquela doce onda lânguida, e saber que a levantava assim a saudade dos meus beijos, eu teria vindo de tão longe a Alexandria; iria mais longe, a pé, sem repouso, até onde as águas do Nilo são brancas! (QUEIRÓS, 2014, p. 78)

Quando a estada no Egito tem seu fim e Teodorico necessita partir num navio que segue para Jesusalém, a amante inglesa prepara-lhe um presente:

Então Maricoquinhas, com uma inspiração delicada, agarrou uma folha de papel pardo; apanhou do chão um nastro vermelho; e as suas habilidosas mãos de luveira fizeram da camisinha um embrulho redondo, cómodo e gracioso que eu meti debaixo do braço, apertando-o com avara, inflamada paixão. (QUEIRÓS, 2014, p. 84)

É também durante a viagem à Terra Santa que o narrador personagem tem um sonho, um sonho com o Diabo, que vez ou outra assume a forma de uma antiga amante lisboeta que o rejeitara, a Adélia. Neste sonho, Teodorico tem uma espécie de viagem metafórica ao passado e vê o surgimento de uma nova religião: 
Assim marchando, chegamos ao alto do monte, onde uma palmeira se desgrenhava sobre um abismo cheio de mudez e de treva. em frente de nós, muito longe, o céu desdobrava-se como um vasto estofo amarelo; e sobre esse fundo vivo, cor de gema de ovo, destacava um negríssimo outeiro, tendo cravadas no alto três cruzinhas em linha, finas e de um só traço. O diabo, depois de escarrar, murmurou, travando-me da manga: "A do meio é a de Jesus, filho de José, a quem também chamam o Cristo; e chegamos a tempo para saborear a Ascensão". Com efeito! A cruz do meio, a do Cristo, desarraigada do outeiro, como um arbusto que o vento arranca, começou a elevar-se, lentamente, engrossando, atravancando o céu. E logo de todo o espaço voaram bandos de anjos, a sustê-la, apressados como as pombas quando acodem ao grão; uns puxavam-na de cima, tendo-lhe amarrado ao meio longas cordas de seda; outros, debaixo, empurravam-na e nós víamos o esforço entumecido dos seus braços azulados. Por vezes do madeiro desprendia-se, como uma cereja muito madura, uma grossa gota de sangue; um serafim recolhia-a nas mãos e ia colocá-la sobre a parte mais alta do céu onde ela ficava suspensa e brilhando com o resplendor de uma estrela. Um ancião enorme de túnica branca, a que mal distinguíamos as feições, entre a abundância da coma revolta e os flocos de barbas nevadas, comandava, estirado entre nuvens, estas manobras da Ascensão, numa língua semelhante ao latim e forte como o rolar de cem carros de guerra. Subitamente tudo desapareceu. (QUEIRÓS, 2014, p. 85-86, grifo nosso)

A nova religião a qual Teodorico vê surgir no sonho é, obviamente, o Cristianismo e percebemos o quanto, mais uma vez, o texto queirosiano descreve este como uma doutrina autoritária, cheia de dor e bruteza. O sonho prossegue e, em seguida, o próprio Diabo descreve o Cristianismo como uma religião tediosa, que pôs fim à alegria e ao prazer próprios das religiões pagãs, que dominavam a maior parte do mundo, antes do seu surgimento.

O texto queirosiano continuará com seu tom herético, que visa dessacralizar as escrituras, os textos bíblicos, através do escárnio, do riso, da ironia. Assim, quando chega às planícies de Canaã, Teodorico encontrará um lugar extremamente desértico e desolado e se surpreenderá quando o historiador alemão, Topsius, seu companheiro de viagem, explicar que aquela região

[...] fora outrora toda coberta de rumorosas cidades, de brancos caminhos entre vinhedos, e de águas de rega refrescando os muros das eiras; as mulheres, toucadas de anémonas, pisavam a uva cantando; o perfume dos jardins era mais grato ao céu que o incenso; e as caravanas que entravam no vale pelo lado de Ségor achavam aqui a abundância do rico Egito - e diziam que era este em verdade o vergel do Senhor. (QUEIRÓS, 2014, p. 110)

E continuará o historiador, afirmando, em tom irônico, que aquele lugar fora próspero e verde até que um dia “[...] dia o Altíssimo aborreceu-se e arrasou tudo!” (QUEIRÓS, 2014, p. 110), fazendo alusão ao modo como Deus, no Velho Testamento, desejando castigar os homens, destrói cidades e regiões inteiras. Teodorico questiona o amigo por qual motivo Deus faria uma coisa dessas e tem a seguinte resposta: "Birra; mau humor; ferocidade..." (QUEIRÓS, 2014, p. 110). Dessa maneira, o cientista alemão e seus comentários representam, na novela de Eça, “[...] o olhar da ciência frente a Religião e desempenhará o papel do ateu frente às crenças 
beatas, questionando, ainda, por assim dizer, o caráter de Deus" (NERY, 2011, p. 4). Nery (2011), ressalta, também, que esse tipo de construção discursiva as quais encontramos nos textos queirosianos prenunciam o modo como a personagem de Deus será representada contemporaneamente, em obras de autores como José Saramago - basta lembrar de como o Criador é representado em O Evangelho Segundo Jesus Cristo.

Portanto, Jerusalém e as regiões santas onde se passam muitos dos principais acontecimentos dos textos bíblicos, seja do Velho ou do Novo Testamento, serão sempre representadas e descritas por Teodorico de forma "ignóbil, miserável e triste, muito diferente daquilo que se conhece dos relatos bíblicos" (NERY, 2011, p. 4). Neste vagar pela Terra Santa, Teodorico Raposo encontra, ainda, uma árvore de espinhos e tem uma brilhante ideia:

Levar à Titi um desses galhos, o mais penugento, o mais espinhoso, como sendo a relíquia fecunda em milagres, a que ela poderia consagrar seus ardores de devota e confiadamente pedir as mercês celestiais! "Se entendes que mereço alguma coisa pelo que tenho feito por ti, traz-me então desses santos lugares uma santa relíquia..." Assim dissera a senhora D. Patrocínio das Neves na véspera da minha jornada piedosa, entronada nos seus damascos vermelhos, diante da magistratura e da igreja, deixando escapar uma baga de choro sob seus óculos austeros. Que lhe podia eu oferecer mais sagrado, mais enternecedor, mais eficaz, que um ramo da árvore de espinhos, colhido no vale do Jordão, numa clara, rosada manhã de missa? (QUEIRÓS, 2014, p. 117)

Com intuito de cumprir a promessa que fizera à tia, Teodorico pensa em levar um galho daquela árvore, argumentando que se tratava da mesma árvore de onde fora tirada a coroa de espinhos de Jesus. Logo após ter esta ideia, no entanto, vemos o Teodorico hesitar diante de um pensamento sombrio:

E se realmente uma virtude transcendente circulasse nas fibras daquele tronco? E se a Titi começasse a melhorar do fígado, a reverdecer, mal eu instalasse no seu oratório, entre lumes e flores, um desses galhos eriçados de espinhos? ó misérrimo logro! Era eu pois que lhe levava nesciamente o princípio milagroso da saúde, e a tornava rija, indestrutível, ininterrável, com os contos de G. Godinho firmes na mão avara! Eu! Eu que só começaria a viver, quando ela começasse a morrer! (QUEIRÓS, 2014, p. 118)

Novamente, percebemos o quanto o português sempre esteve apenas preocupado com a herança da tia, ocultando sua personalidade e verdadeiras intenções, chegando a sonhar com a morte da velha, afinal, ele " $[\ldots]$ só começaria a viver, quando ela começasse a morrer" (QUEIRÓS, 2014, p. 118). Desse modo, ao ser consultado, de modo a responder se aquela árvore poderia ter sido a mesma da qual tirara-se um dia a coroa de espinhos de Jesus, o amigo Topsius, ateu e cientista, historiador e conhecedor dos detalhes mais ínfimos daquela região do planeta, de um modo evidentemente irônico e sarcástico, dirá a Teodorico que aquele galho de espinhos "Foi o mesmo que ensanguentou a fronte do rabi Jeschoua Natzarieh, a quem os latinos chamam Jesus de Nazaré, e outros chamam o Cristo!” (QUEIRÓS, 2014, p. 122). Em verdade, através deste episódio fica patente a representação e crítica ao fanatismo religioso, responsável pelo secular comércio de relíquias falsas, muito comum ainda no século XIX em Portugal. 
Mas, se há um momento em que a ironia e o sarcasmo queirosianos manifestam-se de modo emblemático este momento é o sonho em que Teodorico revisita o passado e vivencia momentos decisivos da paixão de Jesus Cristo. Ele próprio descreverá a si próprio, então, como "[...] uma testemunha inédita da Paixão" (QUEIRÓS, 2014, p. 151), convertendo-se em "S. Teodorico Evangelista" (QUEIRÓS, 2014, p. 151). Evidentemente, como era de se esperar, trata-se de um discurso altamente irônico e aquilo no qual Teodorico Raposo se converte não pode ser chamado de Evangelista no sentido tradicional do termo, mas, antes, deveríamos dizer que ele se transforma numa espécie de Evangelista às avessas ou, se preferirmos, num Desevangelista, na medida em que deturpará completamente os fatos narrados no texto bíblico. Para Bueno (2000), por sua vez, o narrador personagem deve ser encarado como um verdadeiro "Heresiarca" (BUENO, 2000, p. 65).

Sendo assim, é no terceiro capítulo da novela em que Teodorico Raposo narrará esse insólito e herético sonho. Nery (2011), recorrendo a Bakhtin, defenderá que, ao recontar acontecimentos narrados na Bíblia, o narrador queirosiano de $A$ relíquia constrói uma nítida paródia, em que se verifica uma luta entre " [...] dois projetos, dois pensamentos diferenciados, embate esse que pode ser reconhecido por meio de traços linguísticos que marcam a presença da voz do outro, como a ironia, a indignação, a zombaria e a dúvida, por exemplo" (NERY, 2011, p. 5). Em outros termos, pode-se dizer que o leitor facilmente percebe o diálogo intertextual com o Novo Testamento, mais especificamente com os Evangelhos de Mateus, Marcos, Lucas e João. Ora, Teodorico seria, assim, como ele próprio se define, o Quinto Evangelista. Portanto, neste Evangelho às avessas ou, se quisermos, neste Desevangelho, ainda que haja certa intertextualidade com algumas outras obras da literatura ocidental, "[...] o texto bíblico configura-se, contudo, como a principal matriz para o desenvolvimento da paródia" (QUEIRÓS, 2014, p. 5).

No sonho, Teodorico é acompanhado pelo amigo Topsius, que o guia pela Jerusalém dos tempos de Cristo, na véspera da Páscoa Judaica, a fim de presenciar "[...] esta página do Evangelho" (QUEIRÓS, 2014, p. 124). Diferentemente da Terra Santa do século XIX, a qual Teodorico conhecera, em seu sonho, aquelas paisagens eram vivas, verdejantes, cheias de esplendor e glória.

Determinado a tecer um dura crítica religiosa e anticlerical, desconstruindo ao longo do relato a sacralidade da cidade de Jerusalém, bem como a figura de Jesus, como temos visto, Teodorico desafiará até mesmo Deus, duvidando de seu poder, quando chega às portas da cidade santa, acompanhado por Topsius, no sonho: "César pareceu-me mais forte que Jeová" (QUEIRÓS, 2014, p. 133). Na casa da Gamaliel, amigo do historiador alemão, Teodorico presenciará, ainda, um debate entre homens judeus após terem notícia de que o rabi de Nazaré acabara de ser preso. A maioria colocar-se-á contra a figura de Jesus, acusando-o de ser um traidor dos costumes judaicos: "Só Jeová é grande! E em verdade te digo que, quando o rabi Jeschoua, desprezando a lei, dá à mulher adúltera um perdão que tanto cativa o simples, cede à frouxidão da sua moral e não à abundância da sua misericórdia!” (QUEIRÓS, 2014, p. 144).

Nesse sentido, o relato de Teodorico acaba por evidenciar o conflito entre as ideias de 
Jesus e os costumes e crenças judaicas, permitindo que o leitor perceba o quanto está por trás desse texto literário uma vasta pesquisa histórica e teológica por parte de Eça de Queirós, que certamente conhecia bem os Evangelhos. Assim, através de um outro judeu, Manassés, tornase nítida a impossibilidade dos judeus de então aceitarem Jesus com Messias:

Todavia, esse Rabi de Galileia deve decerto morrer, porque é um mau cidadão e um mau judeu! Não o ouvimos nós aconselhar que se pague o tributo a César? O Rabi estende a mão a Roma; o romano não é o seu inimigo. Há três anos que prega, e ninguém jamais lhe ouviu proclamar a necessidade santa de expulsar o estrangeiro. Nós esperamos um messias que traga uma espada e liberte Israel, e este, néscio e verboso, declara que traz só o pão da verdade! Quando há um pretor romano em Jerusalém; quando são lanças romanas que velam às portas do nosso Deus, a que vem esse visionário falar do pão do céu e do vinho da verdade? A única verdade útil é que não deve haver romanos em Jerusalém!... (QUEIRÓS, 2014, p. 147)

Bem se vê o quanto o problema dos judeus era um problema de terra, de dominação territorial, portanto, o Messias o qual esperavam não poderia ser um homem que dizia a todos para amarem o próximo como a si mesmos, para perdoarem seus inimigos e prometia um reino que não é deste mundo. Assim, a novela de Eça, o relato de Teodorico, dá conta de representar a problemática política que envolve a crucificação de Cristo, nos Evangelhos.

Ainda no que concerne ao fatídico sonho de Teodorico Raposo e à descontrução da figura de Cristo, vale mencionar um outro momento em que ele prova o seu caráter de Heresiarca. Trata-se do momento em que o português encontra um vendilhão do tempo, um comerciante, que se queixa de Jesus:

Mas eis que há dias esse Rabi de Galileia aparece no templo, cheio de palavras de cólera, ergue o bastão e arremessa-se sobre nós, bradando que aquela "era a casa do seu pai, e que nós a poluíamos!..." E dispersou todas as minhas pedras, que nunca mais vi, que eram o meu pão! Quebrou nas lajes os vasos de óleo de Eboim, de Jopé, que nem gritava, espantado. Acudiram os guardas do templo. Menahem acudiu também; até, indignado, disse ao Rabi: — "És bem duro com os pobres. Que autoridade tens tu?" E o Rabi falou "de seu pai", e reclamou contra nós a lei severa do templo. Menahem baixou a cabeça... E nós tivemos de fugir, apupados pelos mercadores ricos, que bem encruzados nos seus tapetes de Babilônia, e com o seu lajedo bem pago, batiam palmas ao Rabi... Ah! contra esses o Rabi nada podia dizer; eram ricos, tinham pago!... E agora aqui ando! Minha filha, viúva e doente, não pode trabalhar, embrulhada a um canto nos seus trapos; e os filhos da minha filha, pequeninos, têm fome, olham para mim, vêem-me tão triste e nem choram. E que fiz eu? Sempre fui humilde, cumpro o sabá, vou à sinagoga de Naim que é a minha, e as raras migalhas, que sobravam do meu pão, juntava-as para aqueles que nem migalhas têm na terra... Que mal fazia eu vendendo? Em que ofendia o Senhor? Sempre, antes de estender a esteira, beijava as lajes do templo; cada pedra era purificada pelas águas lustrais... Em verdade Jeová é grande, e sabe... Mas eu fui expulso pelo Rabi, somente porque sou pobre! (QUEIRÓS, 2014, p. 170, grifo nosso)

Como se vê, o vendilhão queixa-se da insensibilidade de Jesus, que, segundo ele, teria expulsado os vendilhões pobres do templo, que não podiam competir com os grandes 
comerciantes ricos. Somente este fato já é suficiente para desconstruir e dessacralizar um dos momentos mais importantes da história de Cristo narrada nos Evangelhos. Contudo, o episódio termina de um modo ainda mais herético e sarcástico, em que o leitor vê Cristo tornar-se devedor do próprio Teodorico Raposo:

E a minha angústia toda era por Jesus ignorar esta desgraça, que, na violência do seu espiritualismo [...] Então para que não houvesse nada imperfeito na sua vida, nem dela ficasse uma queixa na terra - paguei a dívida de Jesus (assim seu pai perdoe a minha!), atirando para o saião do velho moedas consideráveis, dracmas, crisos gregos de Filipe, áureos romanos de Augusto, até uma grossa peça da Cirenaica, que eu estimava por ter uma cabeça de Zeus Amon, que parecia a minha imagem. (QUEIRÓS, 2014, p. 170-171)

Dessa maneira, um dos seus principais objetivos é não só dessacralizar a história mais importante do Cristianismo, narrada nos Evangelhos, mas humanizar a própria a figura de Jesus, que é descrito como um homem comum e sonhador, que comete erros, muito diferente do imponente Cristo de ouro para o qual sua tia beata se prostrava e proferia orações:

E aquele homem não era Jesus, nem Cristo, nem Messias - mas apenas um moço de Galileia que, cheio de um grande sonho, desce da sua verde aldeia para transfigurar todo um mundo e renovar todo um céu e encontra a uma esquina um netenim do templo que o amarra e o traz ao pretor, numa manhã de audiência, entre um ladrão que roubara na estrada de Siquém e outro que atirara facadas numa rixa em Emá! (QUEIRÓS, 2014, p. 155)

A cena da crucificação, assim, é descrita de um modo bastante realista, escatológico, sem quaisquer transcendentalismos - Jesus é apenas um homem de carne e osso que agoniza e que desfalece pouco a pouco:

Então, ansioso, ergui os olhos... Ergui os olhos para a cruz mais alta, cravada com cunhas numa fenda de rocha. O Rabi agonizava. $\mathbf{E}$ aquele corpo que não era de marfim nem de prata, e que arquejava, vivo, quente, atado e pregado a um madeiro, com um pano velho na cinta, um travessão passado entre as pernas - encheu-me de terror e de espanto... $\mathrm{O}$ sangue que manchara a madeira nova, enegrecia-lhe as mãos, coalhado em torno aos cravos; os pés quase tocavam o chão, amarrados numa grossa corda, roxos e torcidos de dor. A cabeça, ora escurecida por uma onda de sangue, ora mais lívida que um mármore, rolava de um ombro a outro docemente; e por entre os cabelos emaranhados, que o suor empastara, os olhos esmoreciam, sumidos, apagados - parecendo levar com a sua luz, para sempre, toda a luz e toda a esperança da terra. (QUEIRÓS, 2014, p. 191, grifo nosso)

Como coloca Bueno (2000), chegamos ao ápice da dessacralização da figura Cristo no fim do sonho, quando temos a notícia de que na verdade ele não morrera na cruz, apenas bebera um vinho narcotizado para simular a morte. Contudo, para surpresa de todos, depois de ser transportado, na calada da noite, do túmulo de pedra onde fora colocado para a casa de José de Ramata, Jesus acabara por vir a falecer: “[...] Depois estremeceu: um pouco de sangue apareceulhe ao canto da boca... E, com a cabeça sobre o peito de Nicodemos, o Rabi ficou morto!" (QUEIRÓS, 2014, p. 209). Em seguida ficamos a saber que depois de morto, ele fora sepultado 
em um outro túmulo, porque "[...] Era necessário, para o bem da terra, que se cumprissem as profecias!". E assim, uma vez mais Teodorico não só cumpre sua função de desconstruir o texto bíblico e a figura do messias cristão, mas torna patente a crítica à religião e ao transcendentalismo, deixando clara sua mensagem herética: o cristianismo é "um embuste, uma lenda" (FERRAZ, 1997, p. 96), tendo nascido de uma mentira, ou melhor, do amor de uma mulher: "Então Maria de Magdala, crente e apaixonada, irá gritar por Jerusalém: - ressuscitou, ressuscitou! E assim o amor de uma mulher muda a face do mundo, e dá uma religião mais à humanidade" (QUEIRÓS, 2014, p. 210).

Os dois capítulos que se sucedem à narração do sonho de Teodorico, darão conta de narrar mais algumas de suas peripécias pelo Oriente Médio e o seu regresso à Portugal. É durante a viagem de volta que ele decide, ainda, desfazer-se do presente que ganhara de sua amante inglesa, em Alexandria. Assim, ele abandona no deserto a evidência do seu pecado, da sua luxúria, a prova de que ele não era nem nunca fora um homem beato e casto, como desejava a tia Patrocínio: o embrulho com a camisola de Mary. Quando finalmente chega à Lisboa, à casa da tia, Teodorico é recebido como um santo e tem a certeza de que seu plano dera certo: "E nada podia desalojar-me do testamento da senhora Dona Patrocínio! Eu tornara-me para ela São Teodorico! A hedionda velha estava enfim convencida de deixar-me o seu ouro" (QUEIRÓS, 2014, p. 236). No entanto, logo em seguida, no momento em que Teodorico entrega à sua tia o embrulho onde supostamente estaria a relíquia santa prometida a ela, a coroa de espinhos de Jesus, temos um dos momentos mais hilariantes e cômicos da novela queirosiana:

Acordando do seu langor, trémula e pálida, mas com a gravidade de um pontífice, a Titi tomou o embrulho, fez mesura aos santos, colocou-o sobre o altar; devotamente desatou o nó do nastro vermelho; depois, com o cuidado de quem teme magoar um corpo divino, foi desfazendo uma a uma as dobras do papel pardo... Uma brancura de linho apareceu... A Titi segurou-a nas pontas dos dedos, repuxou-a bruscamente - e sobre a ara, por entre os santos, em cima das camélias, aos pés da cruz - espalhou-se, com laços e rendas, a camisa de dormir da Mary! A camisa de dormir da Mary! Em todo o seu luxo, todo o seu impudor, enxovalhada pelos meus abraços, com cada prega fedendo a pecado! A camisa de dormir da Mary! E pregado nela por um alfinete, bem evidente ao clarão das velas, o cartão com a oferta em letra encorpada: - "Ao meu Teodorico, meu portuguesinho possante, em lembrança do muito que gozamos!" Assinado, M. M.... A camisa de dormir da Mary! (QUEIRÓS, 2014, p. 249)

Então, ficamos a saber que os embrulhos haviam sido trocados na viagem e que aquele no qual estava guardada a relíquia fora descartado por Teodorico no deserto, para sua completa desgraça, que se vê expulso imediatamente da casa de Dona Patrocínio das Neves. Assim, no fim do relato, Teodorico narrará, ainda, o que aconteceu consigo depois de ser enxotado da casa da tia. Ficamos a saber que a velha morrera em seguida e que tudo o que deixara para ele fora um óculo, de modo que pudesse ver de longe tudo que perdera. É neste momento em que presenciamos um outro momento bastante insólito e fantástico, quando Teodorico tem uma 
visão e conversa com Jesus, que lhe diz:

\begin{abstract}
Quando tu ias ao alto da graça beijar no pé uma imagem — era para contar servilmente à Titi a piedade com que deras beijo; porque jamais houve oração nos teus lábios, humildade no teu olhar — que não fosse para que a Titi ficasse agradada no seu fervor de beata. O deus a que te prostravas era dinheiro de G. Godinho; e o céu para que os teus braços trementes se erguiam - o testamento da Titi... [...] Depois resumiste esse laborioso dolo de uma vida inteira num embrulho - onde acomodaras um galho, tão falso como o teu coração; e com ele contavas empolgar definitivamente as pratas e prédios de D. Patrocínio! Mas noutro embrulho parecido trazias pela Palestina, com rendas e laços, a irrecusável evidência do teu fingimento... Ora, justiceiramente aconteceu que o embrulho que ofertaste à Titi e que a Titi abriu - foi aquele que lhe revelava a tua perversidade! $\mathbf{E}$ isto prova-te, Teodorico, a inutilidade da hipocrisia! (QUEIRÓS, 2014, p. 263, grifo nosso)
\end{abstract}

Diante dessa conversa com Jesus, em que Teodorico tem sua hipocrisia e ambição denunciadas, o leitor pode se sentir tentado a acreditar que ele de fato passa a ter remorsos e que uma mudança em sua personalidade começa a acontecer. Então, em seguida ficamos a saber que após aquela visão, Teodorico decidira agir de modo sincero e franco - é graças a essa suposta mudança de conduta, por exemplo, que nos conta que conseguira, tempos depois, casarse com uma moça rica e abastada, irmã de um amigo, que ficara muito alegre e surpreso diante da franqueza de Teodorico ao lhe contar toda sua história. Contudo, como bem nos lembra Nery (2013), trata-se apenas de uma impressão, que é resultado da fina ironia presente do discurso do narrador personagem da novela de Eça Queirós. O autor defende que é principalmente através da hipocrisia de Teodorico, bem como através da própria hipocrisia de Dona Patrocínio das Neves e de outros personagens, representantes do clero católico, que o discurso irônico se sobressalta e cumpre sua função não só de sátira e galhofa, mas de lançar uma crítica mais profunda a determinados costumes, valores e práticas da sociedade portuguesa do século XIX. Portanto, a leitura de $A$ relíquia requer que tenhamos atenção ao que o autor chama de "camada mais profunda de narração irônica" (NERY, 2013, p. 41), em que residiria, por exemplo, a crítica à corrupção, à hipocrisia, bem como a uma religiosidade medíocre e fanática.

Entrementes, de modo a deixar evidente o quanto o Teodorico que narra não é expressivamente diferente do Teodorico que visitara no passado a Terra Santa, no fim do relato o veremos lastimar a sua falta de astúcia no momento em que a tia abrira o embrulho com a camisola de Mary: “[...] eu deveria ter gritado, com segurança: "Eis aí a relíquia! Quis fazer a surpresa... Não é a coroa de espinhos. É melhor! É a camisa de Santa Maria Madalena!... Deuma ela no deserto..." (QUEIRÓS, 2014, p. 269). Assim, fica patente o quanto todo o seu relato tem, de fato, uma função de dessacralização do texto bíblico e do Cristianismo, podendo ser compreendido, de certa maneira, como temos proposto, como um verdadeiro Desevangelho.

\title{
Conclusão
}

Após essa breve análise, concordamos com Nery (2013) ao defender que aquilo que se pode depreender a partir da leitura de $A$ relíquia é o "enaltecimento de práticas e crenças 
religiosas fora do campo ortodoxo e institucional" (NERY, 2013, p. 52), ou seja, a crítica realizada pelo texto queirosiano parece não visar um ataque radical a todas as formas de fé e vivência transcendental, mas a denúncia e representação da corrupção, da hipocrisia, do fanatismo, do falso moralismo presentes na prática do catolicismo português oitocentista. Nesse sentido, dentro da Teopoética e mais especificamente dentro das discussões da Teologia do Riso, textos literários como $A$ relíquia ganham relevo e importância porque permitem que percebamos a influência da Bíblia sobre a literatura e o modo como esta não apenas cita e se alimenta, de modo intertextual, das narrativas religiosas, mas procura dar-lhes novos contornos, novas interpretações, novos modos de compreendê-las e percebê-las. A arte, sem dúvida, exerce sua função de desautomatização do nosso olhar tantas vezes fixo, auxiliando-nos na percepção de aspectos nos quais normalmente não reparamos. Como temos visto, seja dentro ou fora dos estudos em que se busca comparar e estudar as relações entre a teologia e a literatura, o riso, o humor, o escárnio, a ironia, aliados à arte, cumprem precisamente o seu papel de promover a reflexão e o pensamento crítico.

\section{Referências}

AUERBACH, Erich. Mimesis. São Paulo: Perspectiva, 2011.

BARCELLOS, José Carlos. Teologia e Literatura. In: CEIA, Carlos. E-dicionário de termos literários. Lisboa: [s.n], 2017. Disponível em: http://edtl.fcsh.unl.pt/businessdirectory/7029/teologia-e-literatura/. Acesso em: 17/06/2017.

BIBLIA de Jerusalém. São Paulo: Pauluis, 2015. Tradução Benjamim Carreira de Oliveira (Judite, Eclesiástico); Euclides Martins Balacin (Eclesiastes); Luiz Inácio Stadelman (Jó) et al. Direção Editorial Paulo Bazaglia.

BUENO, Aparecida de Fátima. As Imagens de Cristo nas obras de Eça de Queiroz. 2006. 236f. Tese (Doutorado em Teoria Literária) - UNICAMP, Campinas, 2000.

DUARTE, Lélia Pereira. Ironia e Humor na Literatura. Belo Horizonte: PUC Minas; São Paulo: Alameda, 2006.

FERRAZ, Salma. Adeusinho, adeusinho, cousas da religião! Revista Polifonia, Cuiabá, v. 3, n. 3, p. 86-97, $1997 . \quad$ Disponível em: http://periodicoscientificos.ufmt.br/ojs/index.php/polifonia/article/view/1178/940. Acesso em 26/06/2017.

. É certo que riste: Humor no Cristianismo. In: FERRAZ, Salma; LEOPOLDO, Raphael Novaes. Escritos Luciféricos. Blumenau: Edifurb, 2014, p. 122-146.

. et al. Teologia do riso: humor e mau humor na Bíblia e no Cristianismo. Campina Grande: EDUEPB, 2017.

LEONEL, João; ZABATIERO, Júlio Paulo Tavares. Bíblia, literatura e linguagem. São Paulo: Paulus, 2011. 
MAGALHÃES, Antonio. A Bíblia como obra literária. Hermenêutica literária dos textos bíblicos em diálogo com a teologia. In: MAGALHÃES, Antonio. (Org.). Deuses em Poética. Belém: UEPA; Campina Grande: EDUEPB, 2008. p. 11-24.

NERY, Antonio Augusto. A Jerusalém "Passeada e Comentada" de A Relíquia (Eça de Queirós). Revista Brasileira de História das Religiões, Maringá, v. III, n. 9, 2011. Disponível em: http://www.dhi.uem.br/gtreligiao/pdf8/ST4/001\%20\%20Antonio\%20Augusto\%20Nery.pdf. Acesso em: 25/06/2017.

A Relíquia (Eça de Queiroz): Anticlericalismo e (anti)religiosidade para além da paixão de Cristo. Revista do Curso de Letras da UEPA, Belém, v. 1, n. 1, 2013. Disponível em: https://paginas.uepa.br/seer/index.php/ribanceira/article/download/253/218. Acesso em: 25/06/2017.

QUEIRÓS, Eça de. A Relíquia. Nova Fronteira: Rio de Janeiro, 2014.

QUENTAL, Antero de. Causas da Decadência dos Povos Peninsulares nos últimos três séculos. Lisboa: Edições tinta da china, 2008.

SARAMAGO, José. O Evangelho Segundo Jesus Cristo. Companhia das Letras: São Paulo, 2006.

SILVEIRA, André Luís da. Manifestações humorísticas e subversivas a partir do texto bíblico: um panorama. In: FERRAZ, Salma., et al. Teologia do riso: humor e mau humor na Bíblia e no Cristianismo. Campina Grande: EDUEPB, 2017.

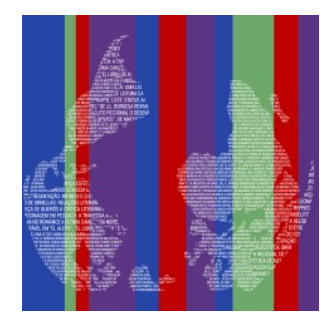

